\title{
HUBUNGAN MALNUTRISI DENGAN GANGGUAN SIKLUS MENSTRUASI DIKAWASAN TEMPAT PEMBUNGAN AKHIR (TPA) SUMOMPO
}

\author{
${ }^{1}$ Sifra T A \\ 2 Joice Kaeng \\ 2 H.M.Tendean
}

\author{
${ }^{1}$ Kandidat Fakultas Kedokteran Unsrat \\ ${ }^{2}$ Bagian Obstetri Ginekologi Fakultas kedokteranUniversitas Sam Ratulangi Manado \\ Email: sifraturuallo_090307@yahoo.com
}

\begin{abstract}
The study used data collection techniques is a survey research with cross sectional analytic contained dikuesioner and interviews conducted in landfills Sumompo November 2012. RESULTS: The data showed that the women who have a BMI of underweight by $22(32 \%)$ female respondents, while women with a normal BMI of 16 (20\%) of respondents while women are overweight by $48(68 \%)$ female respondents. above were found in addition to irregular menstrual cycles on polimenorea respondents 16 $(17 \%)$ of respondents, Normal $13(14 \%)$ of respondents, Oligomenorea $31(32 \%)$ and the most common complaints of the respondents were classified as amenorrhoea sekuder amenorrhoea were $36(37 \%)$ CONCLUSIONS: The majority of respondents were classified into categories indicating a disturbance malnurisi menstrual cycleobtained data on other than an irregular menstrual cycle on respondents Polimenorea, Oligomenorea
\end{abstract}

\section{KEY WORDS: BMI, Poliamenorea, Oligomenorea, amenorrhoea}

\begin{abstract}
Abstrak Penelitian menggunakan cross sectional yang terdapat dikuesioner dan wawancara yang dilakukan di tempat pembuangan akhir (TPA) Sumompo November 2012. HASIL : Data pada menunjukan bahwa wanita yang memiliki IMT underweight sebanyak 22(32\%) responden wanita,sedangkan wanita dengan IMT normal $16(20 \%)$ responden sedangkan wanita yang Overweight sebanyak 48 (68\%)responden wanita. diatas didapati selain siklus menstruasi yang tidak teratur pada responden polimenorea 16(17\%) responden, Normal 13(14\%) responden, Oligomenorea 31(32\%)dan keluhan yang paling sering pada responden amenorea yang digolongkan amenorea sekuder sebanyak 36(37\%) responden priode pada 6 bulan diliat dari usia responden. Sebagian besar responden digolongkan kedalam ketegori malnurisi yang menunjukan adanya gangguan siklus menstruasi data pada didapat selain siklusmenstruasi yang tidak teratur pada responden Polimenorea, Oligomenorea, Amenorea.
\end{abstract}

KATA KUNCI : IMT, Poliamenorea, Oligomenorea,Amenorea 


\section{PENDAHULUAN}

Infertilitas merupakan masalah pada wanita hampir diseluruh dunia. Dari data di Amerika terjadi 25\%-36\% kasus tiap tahunnya.Masalah ini mencapai $45 \%$ dari jumlah populasi wanita dewasa dan merupakan hal yang sangat mengganggu bahkan bisa mengancam keutuhan suatu rumah tangga.Gangguan siklus menstruasi pada wanita merupakan salah satu faktor Infertilitas pada wanita tersebut. ${ }^{1}$

Terjadinya siklus mestruasi adalah perpaduan antara kesehatan genetalian dan rangasan hormonal yang kompleks yang berasal dari mata rantai aksis hipotalamushipofisi-ovarium $^{2}$. Wanita usia reproduksi mengalami keluhan yang berkaitan dengan siklus menstruasi $i^{3}$.Gangguan yang terjadi METODOLOGI PENELITIAN

Jenis penelitian ini merupakan penelitian survei analitik dengan pendekatan cross sectional.

Waktu Penelitian dilaksanakan pada bulan November 2012. Penelitian dilakukan di Kawasan tempat pembuangan akhir (TPA) Populasi pada penelititan ini adalah seluruh wanita dikawasan tempat pembuangan Akhir (TPA). Sampel pada penelitian ini diambil dari populasi yang memenuhi kriteria inklusi dan kriteria eksklusi.

Bahan dan Alat Meteran tinggi badan (Microtoise) ,timbangan berat badan kuesioner, alat tulis data yang dikumpulkan berupa data primer yaitu usia, tinggi badan, berat badan berupa data dari jumlah penduduk total. Peneliti melakukan wawancara kepada responden untuk mengisi lembar informed consent dan kuesioner serta melengkapi lembar observasi penelitian. Pengolahan dan Analisis Data dilakukan setelah jumlah sampel minimal terpenuhi pada bulan November 2012. adalah hipermenorea, hipomenorea, polimenorea, oligomenorea, dan amenorea. ${ }^{2}$

Malnutrisi dikatakan malnurisi juga apabila pada saat pengukuran berat badan kurang dari $90 \%$ berat badan ideal.

atau jika index massa tubuh (IMT) kurang dari 18,5. Selain kriteria tersebut sebenarnya meliputi dua hal yaitu nutrisi kurang dan kebanyakan dari mereka tidak memperhatikan asupan makanan yang mereka makan disebabkan sarana dan prasarana mereka untuk mendapatkan bahan makanan dengan gizi baik tidak terpenuhi, misalnya kurangnya penjual sayuran masuk kekawasan tersebut (Janthje Pausther. Kepala Ling.III,Kelurahan Sumompo).

\section{Definisi Operasional}

Malnurisi adalah nutisi kurang atau nurisi berlebihan ${ }^{2}$.

Dikategorikan menjadi :

1. underweight: $<18,5$

2. Overweight : $>25^{5}$

1.Polimenorea : kurang dari 21 hari

2.Oligomenorea : lebih dari 35 hari

3.Amenorea :

amenorea primer : Tidak adanya menstruasi pada usia 16 tahun

amenorea sekunder: berhentinya menstruasi selama 6 bulan $^{4}$

Pengolahan dan analisis data dilakukan dengan menggunakan program komputer SPSS (Statistical Package for the Social Sciences) versi 17.0. Tingkat kemaknaan yang digunakan adalah $5 \%(\alpha=0,05)$. Jika syarat uji Chi Square tidak terpenuhi maka uji alternatifnya yaitu uji Kolmogorov-Smirnov. Panduan interpretasi hasil uji hipotesis bila nilai $\mathrm{p}$ $<0,05$ (H0 ditolak, Ha diterima) maka terdapat hubungan bermakna antar variabel. 
HASIL PENELITAN

\section{Gambaran umum lokasi penelitian}

Kecamatan Sumompo lingkugan III merupakan salah satu Lingkugan yang menjadi lokasi tempat pembuangan akhir di Kota Manado. Luas wilayah itu \pm 160 ha, berada pada ketinggian suhu maksimum $36,5^{\circ} \mathrm{C}$ dan suhu minimum $23,3^{\circ} \mathrm{C}$ dengan curah hujan berkisar 2000-2500 $\mathrm{mm}^{15}$.

Sebagian besar penduduk bekerja sebagai buru sampah, pemulung, dan penyapu jalan Wilayah ini terletak sekitar 3 $\mathrm{km}$ dari pusat Kota Manado batas selatan Kec. Tuminting, sebelah utara Buha, sebelah timur Wonasa, sebelah barat Buha (Janthje Pausther. Kepala Ling.III,Kelurahan Sumompo).

\section{Krekteristik Responden}

Responden dalam penelitian ini adalah wanita wilayah Tempat pembuangan akhir (TPA) Sumompo kecamatan Sumompo yang diambil dengan teknik rendom sampling. Pengambilan data dengan kategori IMT pada wanita, keluhan siklus menstruasi, Pola makan , makan makronurien ( Protein, Karbohidrat,Lemak), makan mikronutrien ( Mineral, Vitamin), Keluhan-keluhan saat Menstruasi, pemeriksaan IMT melalui pengukuran .Pengambilan data keluhan siklus diperoleh dari wawancara dan kuesioner mengenai frekuensi Keluhankeluhan saat sedangkan dari 26 total 96 responden tidak memiliki keluhan.

\section{.Frekuensi Pola siklus Menstruasi}

\begin{tabular}{lcc}
\hline \multicolumn{1}{c}{ Pola menstruasi } & Frekuensi(n) & $\%$ \\
\hline Poliamenorea & & dib \\
Normal & 16 & 17 tek \\
Oligomenorea & 31 & 14 ga \\
Ameneorea & 36 & 37 \\
& & \\
\hline \multicolumn{1}{c}{ TOTAL } & & 100 \\
\hline
\end{tabular}

\section{PEMBAHASAN}

\section{Pengambilan data melalui koesioner serta penukuran berat badan dan tinggi}

badan. Keluhan siklus pada sebagian besar responden adalah amenorea sekunder. Amenorea sekunder adalah tidak terjadinya menstruasi selama 3 siklus. Menstruasi diperlukan perjalanan atau rantai hormonal dari kelenjar hipotalamus ke hipofisis, kemudian ke indung telur. Rantai hormonal ini juga menstimulasi dinding dalam rahim yang disebut endometrium. ${ }^{8}$ Adanya gangguan pada rangkaian rantai hormonal tersebut akan menyebabkan amenorea sekunder. Aktivitas fisik yang terlalu berat (ekstrem), terlalu kurus (lemak tubuh kurang dari $15-17 \%$ ). Gizi seimbang adalah susunan hidangan sehari yang mengandung zat gizi dalam jumlah dan kualitas yang sesuai dengan kebutuhan tubuh untuk dapat hidup sehat secara sehat. Zat-zat gizi yang dibutuhkan untuk hidup sehat adalah: karbohidrat, protein, lemak, vitamin, dan mineral. $^{5,6,7}$ Didalam tubuh, zat-zat gizi tersebut berfungsi sebagai sumber energi atau tenaga (terutama karbohidrat dan lemak), sumber zat pembangun (protein) terutama dalam melakukan aktivitas kita sehari-hari untuk tetap tumbuh dan berkembang serta untuk mengganti sel-sel yang rusak sumber zat pengatur. ., $^{11,14}$

\section{Distribusi frekuensi IMT pada wanita}

Distribusi frekuensi pada IMT wanita diperoleh dari penimbangan berat badan dan mengukur tinggi badan, pada dasarnya dikatakan malnurisi apabila seseorang tersebut memiliki jumalah nutrisi yang berlebihan dan kekurangan nutrisi dari jumlah yang semestinya yang dibutuhkan sesuai dengan IMT . Menjaga IMT normal bermanfaat menjaga mengurangi risiko terkena penyakit,

17 tekanan darah tinggi, diabetes, stroke serta 14 gangguan hormonal khususnya pada 32 wanita.

37 serta penukuran berat badan dan tinggi 


\begin{tabular}{lccc}
$\begin{array}{l}\text { Distribusi } \\
\text { wanita }\end{array}$ & frekuensi & IMT & pada \\
\hline IMT & Frekuensi(n) & $\%$
\end{tabular}

\begin{tabular}{lcc}
\hline Underweight & 22 & 25 \\
Normal & 16 & 20 \\
Overweight & 48 & 51 \\
& & \\
\hline \multicolumn{1}{c}{ TOTAL } & 96 & 100 \\
\hline
\end{tabular}

\section{Distribusi frekuensi adakah keluhan siklus menstruasi}

Distribusi frekuensi ada tidaknya keluhan yang dirasakan saat menstruasi, normalnya ada selama itu tidak menganggu aktifitas bahkan sampai menghambat aktivitas . Keluhan yang sering dikeluhkan biasanya adanya gangguan siklus menstruasi. Siklus menstruasi yang tidak teratur bisa menjadi tanda awal masalah kesehatan terutama pada wanita yang serius.

\section{Distribusi frekuensi Pola siklus Menstruasi}

\section{Distribusi frekuensi Pola makan}

\begin{tabular}{lcc}
\hline \multicolumn{1}{c}{ Pola makan } & Frekuensi(n) & $\%$ \\
\hline 1-2x perhari & 56 & 58 \\
2-3x perhari & 19 & 20 \\
lebih dari 3x per hari & 21 & 22 \\
& & \\
\hline \multicolumn{1}{c}{ TOTAL } & 96 & 100 \\
\hline
\end{tabular}

Siklus menstruasi adalah serangkaian periode dari perubahan yang terjadi berulang pada uterus dan organ-organ yang dihubungkan pada saat pubertas dan berakhir pada saat menopause. ${ }^{5}$ Siklus tersebut bervariasi dari 18 sampai 40 hari, rata-rata 28 hari. Siklus menstruasi kadangkadang digambarkan pada istilah siklus uterus dan ovarium karena perubahan yang bersamaan yang terjadi pada organ-organ tersebut (Hamilton, 1995). Macam-macam kelainan yang ditemukan didaerah penelitian ialah polimenorea dapat disebabkan oleh gangguan hormonal yang mengakibatkan gangguan ovulasi atau menjadi pendeknya masa luteal Zat Besi yang di konsumsi contohnya zat besi pada susu, pada konsumsi wanita tersebut. Amenorea sendiri dibagi menjadi 2 yaitu : amenorea primer tidak adanya menstruasi pada usia 16 tahun, disebabkan oleh hal-hal yang sulit diketahui, seperti kelainan-kelainan kongenital dan kelainan-kelainan genetik dan amenorea sekunder adalah berhenti atau pernah menga tetapi berhenti berturut-turut selama 3 bulan.pada daerah penelitian terbanyak kasus yang dikeluhan ananya gangguan siklus ${ }^{10,11}$

Kelainan sistemik wanita yang tubuhnya sangat gemuk atau kurus hal ini bisa mempengaruhi siklus menstruasinya karena sistem metabolisme.

\section{KESIMPULAN}

Sebagian besar responden digolongkan kedalam ketegori malnurisi yang menunjukan adanya gangguan siklus menstruasi data pada didapat selain siklus menstruasi yang tidak teratur pada responden Polimenorea 16 (16\%) responden, Oligomenorea $13(13 \%)$ responden, Amenorea 36(36\%) diketahui keluhan yang paling sering pada responden amenorea yang digolongkan amenorea sekuder sebanyak 36 (36\%) responden yang berhubungann dengan IMT pada responden didapati paling banyak IMT underweight dan IMT Overweight. 
SARAN

Para wanita perlu menjaga IMT dengan cara perlu menjaga kebutuhan gizi seimbang dengan memakan makanan yang bergizi untuk menghindari keluhan siklus dan keluahan tambahan yang sampai menghambat aktifitas sehari-hari.

\section{Daftar pustaka}

1. RamliRosdiana.penyebabmasalah kesuburan.http://bidanku.com/ind ex./penyebab-masalah-kesuburan.

2. Price A. Sylvia, wilsson $\mathrm{m}$. Lorraine. Gangguan sistem reproduksi perempuan. Editor: hartanto huriawati, wulansari pita, susi natalia,mahanani asih dewi. Patofisiologi:kosep klinis prosesproses penyakit.edisi6,vol 2. Jakarta: ECG,2003.h.1279-86

3. Norwitz errol, schorge jhon. At a Glance Obstetri dan ginekologi. Editor: amalia safari, rina astikawat.edisi

2.Jakarta.Erlangga:2008.h 46-7.

4. Wiknojososastro hanifa. Ilmu kandungan,edisi 2,cet 7.Jakarta. PT. Bina pustaka sarwono Prawirohardjo,2009.h204-29

5. Sudoyono.w.aru,setiyohadi bambang , alwi idurus, k.simadibrata marcellus,setias siti, editors. Buku ajar Ilmu penyakit dalam.malnutisi.Jilid 1 , edisi V . Jakarta. Internapublishing:2009.h 354-57

6. Proverwati atikah, asfuah siti. Gizi untuk kebidanan. Bab 3. Zat Gizi Makro.Yogyakarta.Muha medika.2009.h10-21.

7. Selvia mega.Hubungan status gizi dengan menstruasi.2010 feb 28 diunduh:

http://www.wrp.diet.wordpress.co $\underline{\mathrm{m}}$

8. Nutrisi sehat untuk wanita dan siklus

bulanannya. diunduh:http://emedicine.medsca

pe.com

9. Kesehatan dan kewanitaan: Fisioligi menstruasi. Diunduh: http://www.klinikdokter.com.

10. Proverwati atikah, asfuah siti. Gizi untuk kebidanan. Bab 4. Zat Gizi makro.Yogyakarta.muha medika.2009.h24-34.

11. Proverwati atikah, asfuah siti. Gizi untuk kebidanan. Bab10. Zat Gizi seimbang bagi anak dan remaja dewasa.Yogyakarta.muha medika.2009.h141-148.

12. Saifuddin bari abdul,rachimitaaadi trimajto editors. Ilmu kandungan haid dan siklusnya.edisi 2. cet 7.Jakarta: PT. Bina pustaka sarmoro prawiroharjo.2009.h 204-05

13. Zulkarnaen L.andea.menstruatin disorders.2012 mar 29. Diunduh:http://emedicine.medcap e.com

14. Proverwati atikah, asfuah siti. Gizi untuk kebidanan. Bab16 .Gizi dalam kesehatan reproduksi.Yogyakarta.Muha medika.2009.h202-06.

15. Tamoid E.Zetly. Karakteristik mutu udara dipusat dan sekitar TPA sumompo. Vol.2. 2008

16. Gizi remaja putri.2012 des 27 diunduh

http://www.Remaja+wanita+disar ankan+untuk+mengonsumsi+mak anan+dengan+gizi+yang+seimba ng+agar+status+gizinya+baik $+\mathrm{He}$ ryati $+\% 282005 \% 29 \&$ oq $=$ Remaja +wanita+disarankan+untuk+men gonsumsi+makanan+dengan+gizi +yang+seimbang+agar+status+gi zinya+baik + Heryati.com

17. Tidak haid 4 bulan.2012 des 17 diunduh http://m.klikdokter.com/ekonsulta si/read/3728/tidak-haid-4-bulan.

18. Ciri wanita yang tidak mendapatkan menstruasi.2012 
des

27.

diunduh:http://www.dokter.com/t entang/ciri-wanita-tidak-akanmendapat-siklus-menstruasi.html

19. Hindari asupan kalori terlalu banyak. 2012 des 28. Diunduh:http://www.farmasiku.c om/index.php?target=pages\&pag e_id=Menghindari_Asupan_Kole strol_Terlalu_banyak

20. Konsep dasar ilmu gizi.2012 des 28.diunduh

http://www.lusa.web.id/konsepdasar-ilmu-gizi/

21. Apa itu mikronutrien. 2012 des 28.diunduh:

http://olvista.com/kesehatan/apaitu-mikronutrien/
22. Hubungan status gizi dengan menstruasi.2013 jan 3 diunduh:http://blogs.unpad.ac.id/f undamentalofnursing2fafaferary/

23. PENYEBAB GANGGUAN SIKLUS MENSTRUASI. 2012 jan 18 . diunduh : http://lira-yfkm11.web.unair.ac.id/artikel_det ail-41360-Umum-

MENSTRUASI\%20DAN\%20PE

NYEBAB\%20GANGGUAN\%20 SIKLUS\%20MENSTRUASI.htm 1

24. Pola.Makan.untuk.Mengembalika n.Masa.Menstruasi 2012 jan 18. Diunduh:http://female.kompas.co $\mathrm{m} / \mathrm{read} / 2012 / 07 / 18 / 10065658 / \mathrm{Pol}$ a.Makan.untuk.Mengembalikan. Masa.Menstruasi. 